\section{'Greenpac', a New Peach Hybrid Rootstock Adapted to Mediterranean Conditions}

\author{
Jorge Pinochet ${ }^{1}$ \\ Agromillora Catalana S.A., Research and Development, El Rebato s/n, \\ Subirats, Barcelona 08739, Spain
}

Additional index words. nematode resistance, Meloidogyne spp. almond, tolerance, iron chlorosis, clonal propagation

'Greenpac' is a new peach hybrid rootstock [Prunus persica (L.) Batsch $\times P$. davidiana (L.) Batsch $] \times[P$. dulcis (Mill.) D.A.Webb $\times P$. persica $]$ developed by Agromillora Iberia, S.L., Barcelona, Spain, for use mainly as a rootstock for peach and nectarine cultivars but can also be used for almond. Trees are green leaf with a vigor comparable to that of 'GF 677' or 'Garnem' (Felipe, 2009). Plants propagate well by in vitro and exhibit a uniform growth in the nursery that allows early budding. 'Greenpac' is root knot nematode-resistant to the main species found in the Mediterranean area such as Meloidogyne incognita (Kofoid and White) Chitwood and $M$. javanica (Treub) Chitwood. It has a tolerance to iron chlorosis capable of withstanding high levels of active lime $(10 \%$ to $11 \%$ ) in the field. In a drip-irrigated field trial established in heavy soil with $8 \%$ active lime, the clone was highly productive (Table 1) with a better cropping efficiency than several high-vigor peach and peach $\times$ almond hybrid rootstocks. It also adapts well to different soil textures but prefers well-drained soils. Chilling requirements are low.

\section{Origin}

The original seedling was selected from a cross made between the peach-almond hybrid 'Felinem' as a female parent (Felipe, 2009) and the hybrid peach 'Cadaman ${ }^{\circledR}$, $(P$. persica $\times P$. davidiana $)$ as the pollen donor. 'Felinem' was chosen for its high level of tolerance to iron chlorosis. 'Cadaman ${ }^{\circledR}$, was chosen for its broad resistance against root knot nematodes (Pinochet et al., 1999), good adaptation to Mediterranean environ-

Received for publication 17 Mar. 2009. Accepted for publication 17 Apr. 2009.

I gratefully acknowledge the technical assistance and advice of Dr. Antonio Felipe. I also thank many colleagues within Agromillora as well as outside collaborators for their help that made possible the development of this rootstock. Many thanks to Joan Torrents, Marisa Cunill, Salvador Durán, Diego Díaz, Santiago Navarro, Christophe Bouchet, Juan Negueroles, Luis Angel Pérez, José Luis Espada, Francisca Hernández, Pilar Legua, and Antonio Sánchez.

${ }^{1}$ To whom reprint requests should be addressed; e-mail jpinochet@agromillora.com. ments, and high cropping efficiency with peach and nectarine cultivars (Edin and Garcin, 1994). Breeding was carried out at Agromillora Iberia, S.L. in Barcelona, Spain, and the clone initially was designated and tested as PAC 9904-01. The selection process against biotic and abiotic stress factors was conducted in Barcelona and field-tested in several other geographical areas of Spain from 1999 to 2008 .

\section{Description}

Unbudded trees are vigorous with a very uniform growth. They have an intermediate growth habit between peach and almond although tending more toward the vigorous terminal growth habit of the peach. The root system extends out and downward with a large mass of medium and small fibrous roots. Leaves are lanceolated, medium size ranging between 11 and $14 \mathrm{~cm}$ in length, and are more peach-like than almond-like. Coloration is intense green with wavy serrated margins. Leaf petioles are medium in length ranging from 13 to $16 \mathrm{~mm}$ and channelled, having two short stipules and an absence of nectaries. Active growing shoots exhibit an intermediate green turning into an intensive green color as they mature in the season. The first-year shoots are straight with little feathering. These are green in color with (Armillaria sp.).

yNonsignificant. significantly different (least significant difference, $P=0.05$ ).

TCSA $=$ trunk cross-sectional area. brownish areas that turn into continuous brown-purplish tones during winter dormancy. The lengths of internodes are medium to long ranging from 25 to $35 \mathrm{~mm}$. Flowers are Rosaceae type (showy). Branches normally bear one flower per bud node. Blooming occurs early in the season producing medium-sized flowers with white elliptic petals ranging between 8 and $10 \mathrm{~mm}$ in length and 6 and $8 \mathrm{~mm}$ in width. The flower has between 20 and 25 stamens and one pistil that remains at the same level of the anthers. Trees are nonfruit-bearing. So far, no fruits have been produced in 7-year-old trees. Chilling requirements seem to be low in the range of 400 to 600 chill units comparable to those of 'Garnem', 'Hansen 536' (Kester and Asay, 1986), or 'Barrier ® 1' peach.

\section{Propagation}

'Greenpac' propagates by hardwood cuttings, although with difficulty. However, its propagation by in vitro is outstanding showing the best aptitude for micropropagation among 10 different stone fruit rootstocks, including 'GF 677', which is considered one of the most efficient Prunus rootstocks for in vitro propagation (Table 2). Initial stages of growth in the greenhouse present little or no branching and an even rate of growth habit. Nongrafted plants are vigorous and in the nursery, they exhibit an erect growth. The percentage of bud take is high for all known peach and nectarine cultivars.

\section{Resistance and Tolerances}

Root knot nematode damage is widespread and constitutes an important limitation in many peach-producing areas of the Mediterranean basin (Pinochet, 1997). The clone was tested on two occasions against this pest. In the first greenhouse trial conducted in 2002, it was found to be resistant to a mixture of five populations of $M$. incognita (unpublished data). A mixture of populations isolated from the Prunus host was used to include a broader spectrum of pathogenicity

Table 1. Field performance and tree survival of 10 rootstocks grafted with the nectarine cultivar Ambra in an 8-year field trial established on a heavy soil with an $8 \%$ active lime content in Tarragona, Spain.

\begin{tabular}{lccccc}
\hline Rootstock & $\begin{array}{c}\text { TCSA } \\
\left(\mathrm{cm}^{2}\right)\end{array}$ & $\begin{array}{c}\text { Cumulative } \\
\text { production } \\
(\mathrm{kg} / \text { tree })\end{array}$ & $\begin{array}{c}\text { Yield } \\
\text { efficiency } \\
\left(\mathrm{kg} \cdot \mathrm{cm}^{-2}\right)\end{array}$ & $\begin{array}{c}\text { Mean } \\
\text { fruit } \\
\mathrm{wt}(\mathrm{g})\end{array}$ & $\begin{array}{c}\text { Number of } \\
\text { dead trees }^{\mathrm{z}}\end{array}$ \\
\hline GF 677 & $96.2^{\mathrm{y}}$ & $85.6 \mathrm{~b}^{\mathrm{x}}$ & $0.89 \mathrm{ab}$ & $169 \mathrm{~b}$ & $2(26)$ \\
Barrier ${ }^{\circledR}$ 1 & 93.1 & $89.3 \mathrm{~b}$ & $0.96 \mathrm{a}$ & $189 \mathrm{a}$ & $5(19)$ \\
Cadaman $^{\circledR}$ & 95.8 & $100.5 \mathrm{a}$ & $1.04 \mathrm{a}$ & $173 \mathrm{~b}$ & $1(19)$ \\
Felinem & 114.9 & $85.4 \mathrm{~b}$ & $0.74 \mathrm{~b}$ & $168 \mathrm{~b}$ & $4(26)$ \\
Garnem & 99.7 & $88.9 \mathrm{~b}$ & $0.89 \mathrm{ab}$ & $171 \mathrm{~b}$ & $2(27)$ \\
PAC 9917-26 & 88.8 & $85.8 \mathrm{~b}$ & $0.93 \mathrm{ab}$ & $178 \mathrm{~b}$ & $0(27)$ \\
Greenpac & 99.7 & $104.2 \mathrm{a}$ & $1.03 \mathrm{a}$ & $175 \mathrm{~b}$ & $4(25)$ \\
PAC 9903-01 & 102.5 & $72.2 \mathrm{c}$ & $0.72 \mathrm{~b}$ & $170 \mathrm{~b}$ & $0(24)$ \\
BH-4 & 108.9 & $92.8 \mathrm{ab}$ & $0.85 \mathrm{ab}$ & $172 \mathrm{~b}$ & $5(27)$ \\
Mayor & 123.5 & $73.4 \mathrm{c}$ & $0.59 \mathrm{c}$ & $168 \mathrm{~b}$ & $19(26)$ \\
\hline
\end{tabular}

zTrial established in a peach replant site with a history of root knot nematodes and oak root fungus

${ }^{x}$ Data are means of 19 to 27 replications. Means within a column followed by the same letter are not 
(Esmenjaud et al., 1994; Marull et al., 1994). A second trial was conducted in 2008 with $M$. javanica. Inoculum originally isolated from Prunus was cultivated and extracted from tomato roots (Hussey and Barker, 1973). Plants were inoculated with 20,000 nematodes per plant, maintained in a greenhouse, and harvested $180 \mathrm{~d}$ after inoculation. Nematode galling and reproduction were assessed according to the method described by Pinochet et al. (1996). 'Greenpac' showed a moderately resistant response (Table 3 ). Incipient galling was observed, although the nematodes did not reproduce well (nonreproducing galls) indicating that a resistance mechanism (hypersensitive reaction) suppressed nematode development resulting in the disruption of the life cycle (Marull et al., 1994). The minor galling observed with little or no nematode reproduction is considered not to be important in terms of field performance.

'Greenpac' has shown to be tolerant to iron chlorosis in several field trials withstand-

Table 2. Mean values of in vitro propagation efficiency (initiation phase, proliferation, rooting, and acclimatization) and initial growth under greenhouse conditions of 10 Prunus rootstocks based on a 0 to 5 rating $(0=$ least desired; $5=$ optimum $)$.

\begin{tabular}{lc}
\hline Rootstock & Propagation efficiency \\
\hline Greenpac & 4.75 \\
GF 677 & 4.6 \\
Krymsk $^{\circledR} 1$ & 4.5 \\
Garnem & 4 \\
PAC 9917-26 & 4 \\
Evrica & 3.75 \\
Marianna 2624 & 3.75 \\
Barrier $^{\circledR} 1$ & 3.75 \\
Adesoto 101 & 3.5 \\
Cadaman $^{\circledR}$ & 3.25 \\
\hline
\end{tabular}

Table 3. Galling and reproduction of a mixture of three isolates of Meloidogyne javanica on 10 peach and plum rootstocks at $180 \mathrm{~d}$ after inoculation with 20,000 eggs and larvae per plant.

\begin{tabular}{lcccc}
\hline Rootstock & $\begin{array}{c}\text { Number of } \\
\text { galls per } \\
\text { root system }\end{array}$ & $\begin{array}{c}\text { Final } \\
\text { nematode } \\
\text { population } \\
\text { in root system }\end{array}$ & $\begin{array}{c}\text { Nematodes } \\
\text { per gram } \\
\text { of root }\end{array}$ & $\begin{array}{c}\text { Resistance } \\
\text { rating }^{\mathrm{y}}\end{array}$ \\
\hline PAC 0301-12 & $0 \mathrm{a}^{\mathrm{x}}$ & $0 \mathrm{a}$ & $0 \mathrm{a}$ & $\mathrm{HR}$ \\
PAC 0303-01 & $0 \mathrm{a}$ & $0 \mathrm{a}$ & $0 \mathrm{a}$ & $\mathrm{HR}$ \\
PAC 00-05 & $0 \mathrm{a}$ & $0 \mathrm{a}$ & $0 \mathrm{a}$ & $\mathrm{HR}$ \\
PAC 941 & $0 \mathrm{a}$ & $0 \mathrm{a}$ & $0 \mathrm{a}$ & $\mathrm{HR}$ \\
PAC 9917-26 & $6 \mathrm{ab}$ & $18 \mathrm{ab}$ & $1 \mathrm{a}$ & $\mathrm{R}$ \\
Garnem & $12 \mathrm{ab}$ & $42 \mathrm{ab}$ & $2 \mathrm{a}$ & $\mathrm{R}$ \\
PAC 0024-01 & $26 \mathrm{~b}$ & $198 \mathrm{~b}$ & $7 \mathrm{a}$ & $\mathrm{MR}$ \\
Greenpac & $29 \mathrm{~b}$ & $87 \mathrm{ab}$ & $6 \mathrm{a}$ & MR \\
Montclar & $276 \mathrm{c}$ & $59,970 \mathrm{c}$ & $2,330 \mathrm{~b}$ & $\mathrm{~S}$ \\
GF 677 & $400 \mathrm{c}$ & $98,020 \mathrm{c}$ & $2,790 \mathrm{~b}$ & $\mathrm{~S}$ \\
\hline
\end{tabular}

${ }^{\mathrm{z}}$ Data are means of six replications. Actual data are presented, but data were transformed to $\log _{10}(\mathrm{x}+1)$ for analysis.

${ }^{\mathrm{y}} \mathrm{HR}=$ highly resistant; $\mathrm{R}$ = resistant; $\mathrm{MR}=$ moderately resistant; $\mathrm{S}=$ susceptible.

${ }^{\mathrm{x}}$ Means within a column followed by the same letter do not differ significantly according to Fisher's least significant difference test $(P=0.05)$.
Lindl.) cultivars, although the range of tested cultivars is not extensive.

\section{Availability}

Registration of 'Greenpac' is in progress at the Community Plant Variety Office, 49101 Angers, Cedex 02, France, with the reference of requesting authority $\mathrm{N}^{\circ} 2006 /$ 2252. Virus- free material is available from Agromillora Iberia, El Rebato s/n, 08739 Subirats Barcelona, Spain. 'Greenpac' is currently marketed in Spain and Europe by several nurseries under the commercial Trademark name ROOTPAC ${ }^{\circledR} 90$.

\section{Literature Cited}

Edin, M. and A. Garcin. 1994. Un nouveau portegreffe du pêcher Cadaman ${ }^{\circledR}$. Avimag. Infos Ctifl $\mathrm{N}^{\circ}$ 99:38-42.

Esmenjaud, D., J.C. Minot, R. Voisin, J. Pinochet, and G. Salesses. 1994. Inter and intraspecific variability in Myrobalan plum, peach and peach-almond rootstocks using 22 root-knot nematode populations. J. Amer. Soc. Hort. Sci. 119:94-100.

Felipe, A. 2009. 'Felinem', 'Garnem' and Monegro' almond $\times$ peach hybrid rootstocks. HortScience 44:196-197.

Hussey, R.S. and K.R. Barker. 1973. A comparison of methods of collecting inocula of spp. including a new technique. Plant Dis. Rptr. 57:1025-1028.

Jiménez, S., J. Pinochet, A. Abadía, M.A. Moreno, and Y. Gogorcena. 2008. Tolerant response to iron chlorosis of Prunus selections as rootstocks. HortScience 43:1-6.

Kester, D.E. and R.N. Asay. 1986. Hansen 2168 and Hansen 536: Two new Prunus rootstock clones. HortScience 21:331-332.

Layne, R.E.C. 1987. Peach rootstocks, p. 185-216. In: Rom, R.C. and R.F. Carlson (eds.). Rootstocks for fruit crops. Wiley, New York, NY.

Marull, J., J. Pinochet, A. Felipe, and J.L. Cenis. 1994. Resistance verification in Prunus selections to a mixture of 13 Meloidogyne isolates and resistance mechanisms of a peach-almond hybrid to M. javanica. Fundam. Appl. Nematol. 16:85-92.

Pinochet, J. 1997. Breeding and selection for resistance to root-knot and lesion nematodes in Prunus rootstocks adapted to Mediterranean conditions. Phytoparasitica 25:271-274.

Pinochet, J., M. Anglés, E. Dalmau, C. Fernández, and A. Felipe. 1996. Prunus rootstock evaluation of root-knot and lesion nematodes in Spain. J. Nematol. 28:616-623.

Pinochet, J., C. Calvet, A. Hernández Dorrego, A. Bonet, A. Felipe, and M.A. Moreno. 1999. Resistance of peach and plum rootstocks from Spain, France and Italy to root-knot nematode Meloidogyne javanica. HortScience 34:12591262.

Pinochet, J., C. Fernández, M. Cunill, J. Torrents, A. Felipe, M.M. López, B. Lastra, and R. Penyalver. 2002. Response of new interspecific hybrids for peach to root-knot nematode and lesion nematodes, and crown gall. Acta Hort. 592:707-716. 